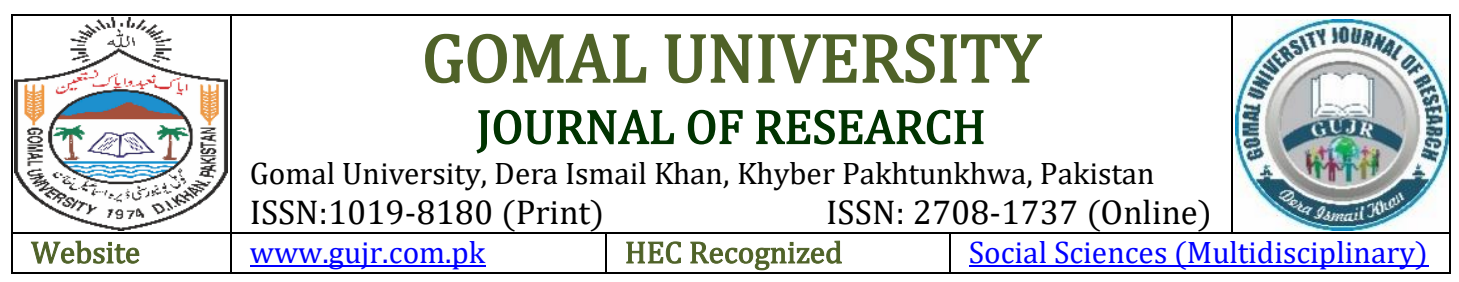

\title{
CPEC THROUGH THE LENS OF PRINT MEDIA: COMPARATIVE ANALYSIS OF ENGLISH NEWSPAPERS OF PAKISTAN AND CHINA
}

\author{
Waqar Ahmad' ${ }^{1}$ Sajjad Ali² \& Zahid Yaseen ${ }^{3}$ \\ ${ }^{1}$ Department of Media \& Communication Studies, University of Swat, KP, Pakistan \\ ${ }^{2}$ Department of Journalism \& Mass Communication, University of Malakand, Pakistan \\ ${ }^{3}$ Department of Political Science, GC, Women University, Sialkot, Punjab, Pakistan
}

\section{ARTICLE INFO \\ Keywords: \\ Assessment, Agenda \\ Setting, CPEC, \\ Comparison, The News \\ International, China \\ Daily}

Article History:

Date of Submission:

06-04-2020

Date of Acceptance:

20-12-2020

Date of Publication:

31-12-2020

\section{ABSTRACT}

This study aimed at evaluating print media's agenda regarding China Pakistan Economic Corridor (CPEC), flagship Belt and Road initiative, and a huge development plan between China and Pakistan. For this purpose, researchers collected data from a Pakistani newspaper The News International and a Chinese newspaper Daily China to compare the portrayal of CPEC. Quantitative analysis was used for collection of data, which was collected through purposive sampling. The timeframe of the study is from January 1, 2018, to June 30, 2018. The results supported the study's objectives and hypotheses. It is concluded that both the newspapers covered CPEC; however, The News International published more CPEC-related project stories than China Daily. The former paper published 57 news stories, while the latter published 33 . The variables of the study were revenue and economy, services and employment, transport \& infrastructure, energy \& power, investment and security, debt and economic aid, environmental destruction, cheap labor, ethnic conflict and international, and sovereignty. Study revealed that both newspapers framed the project positively, although some frames were negative.

\section{(c) (i) (9)}

2020 Gomal University Journal of Research

Corresponding Author

Waqar Ahmad: waqar.jmc.uos@gmail.com

DOI $\quad$ https://doi.org/10.51380/gujr-36-02-07

\section{INTRODUCTION}

Media in recent decades has turned out to be a vital factor in influencing society. It has become the mirror of the society by reflecting the real image, apart from the fundamental functions i.e., to inform, educate, and entertain (Mengal, Hussain, Taj, Liang \& Taj, 2018). The mass media is dominant player in spreading awareness about development projects in any country (Elizabeth \& Aransi, 2020). Media around the globe is generating a phenomenal sensation nowadays by highlighting CPEC (China Pakistan Economic Corridor) as a game-changer and most important 
economic project for the region. Once it is finished, it will change the fate of the region, and the press of both China and Pakistan acts as a bridge between the authorities and the stakeholders. Thus, this study has been conducted to assess the press agenda and the coverage given to China Pakistan Economic Corridor by print media, particularly The News International and China Daily (Mirza, Fatima \& Ullah, 2019). China Pakistan Economic Corridor is the largest mutuallybenefitting development project between Islamic Republic of Pakistan and People's Republic of China, and it is most likely to boost the economic connectivity between the two countries (Malik, 2018).

CPEC is a flagship project of the Belt and Road Initiative (BRI), an important economic corridor, where China has promised to invest $\$ 57$ Billion dollars. With 14 billion dollars already invested in the initial 30 projects, this multi-billion-dollar investment will certainly lead to the economic prosperity in the region. This research analyzed ten frames in news stories of two newspapers likewise The News International and Daily China, namely Revenue and Economy, Services and Employment, Transport \& Infrastructure, Energy and Power, Investment and security, Debt and Economic aid, Environmental destruction, Cheap labor, Ethnic conflicts, and the International relations, and the Sovereignty (Hussain, 2017). The China Pakistan Economic Corridor has been considered as the sign of development for both the countries from different perspectives. China Pakistan Economic Corridor is being understood as a significant project for Pakistan since it is expected to quickly boost the country's plummeting economy. The leading newspapers of the countries are considered as opinion-makers, which provide informative news stories to motivate all the stakeholders. Yousafa, Ahmedb and Fiazc (2018) found that the leading press of Pakistan is playing significant role in the success of CPEC by positively reporting all the issues around the subject.

\section{Importance of Study}

The aim of this study is to find out the role of print media of Pakistan and China in promoting CPEC-related projects because it is playing an effective role in the promotion of both countries' issues and problems and development projects. The study will, on the one hand, measure the level of the coverage and, on the other hand, explain the factor of the CPEC in the development process.

\section{Statement of Problem}

Both the countries are highlighting CPEC in the premise of Pakistan-China friendship and its economic and social prosperity. This study is being conducted to explore how the print of both countries covered it's important for the relation between the two countries and what changes it could bring in the economic uplifting of both the countries. This research has been conducted with the aim to find out the differences in project's portrayal by the newspapers of China and Pakistan.

\section{Objectives of Study}

$\checkmark$ To find out that which newspaper gives more coverage to the CPEC project in both the countries.

$\checkmark$ To explore the comparative coverage of the set frames in the news stories of both the newspaper regarding CPEC.

$\checkmark$ To explore the coverage of both newspapers based on its nature about China Pakistan Economic Corridor. 


\section{Research Hypothesis}

The below-mentioned hypotheses have been emerged from the main theme of the current study:

H1: China Daily and The News International give positive coverage to revenue and economy than debt and economic aid regarding CPEC.

H2: The News International framed more news stories about transport and infrastructure regarding CPEC as compared to China Daily

H3: The News International and China Daily framed the coverage of energy and power in a positive way rather than ethnic conflicts and international relations.

$\mathrm{H}_{4}$ : The News International gives more coverage to services and employment as compared to China Daily regarding CPEC.

H5: China Daily and The News International give positive coverage to investment and security as compared to sovereignty.

\section{LITERATURE REVIEW}

Pakistan and China share the long history of friendship and mutually beneficial relations on the international level (Farooq, 2020). Therefore, China Pakistan Economic Corridor, a 57 billion US dollar project, will cement the ties between the two countries. This joint venture will provide China a short and easy route for its business with the rest of the world and will certainly support the plummeting economy and infrastructure and energy sectors of Pakistan. According to media development investment fund website (2014), free media could play an important role to reduce corruption, increase the economic stability, improve governance, and bring positive social and environmental change in society. Mangal et al. (2018) analyzed news stories regarding CPEC in Dawn and Jang newspapers. They found that there was less coverage of CPEC before its launch as compared to the coverage after its launch. They found that media reported the project as "in the favor of Pakistani nation" and highlighted its importance for the region of South Asia and found media coverage of CPEC to be favorable after its launch. Moreover, some stories were part of the Pakistani government's media campaign. The news stories after launch of the CPEC were "more informative and descriptive in nature" as compared to the stories before the launch of the project.

Furthermore, even though some reservations exist, analysis of various stories of top Pakistani and Chinese newspapers reveals that coverage of CPEC projects was largely positive and some issues were more covered than others (Yousaf, 2018). Besides, CPEC will provide a secure and lower cost passage for Chinese to the Middle East and Europe through CPEC (Alam, Li \& Baig, 2019). China is considered the second-largest economy in the world. In the year 2016, 40\% of trade was transported via the South China Sea. After the completion of the road from Kashgar to Gawadar, China will be able to reduce the distance and time frame from the Europe and the Middle East by 12,000 KM and 23 days. News related to CPEC has been analyzed by contents analysis of English newspapers of Pakistan. The English print media covered the issue positively in the sense of the economic, relations, environmental impacts and revenue (Hammed \& Hamid, 2016). Therefore, the CPEC project would overcome the poverty and energy crisis in Pakistan although it has been facing challenges in its implementation. It would also be beneficial for the environmental balance, infrastructure, and the economic development as well as would bring prosperity and peace (Abid, \& Ashfaq, 2015). On the other hand, CPEC is a mega project between Pakistan and China to attract international investors, However, it is facing security issues (Dong, 2016). 


\section{Theoretical Framework}

This research is based on the Agenda Setting Theory assumption. As the media set agenda for the masses to think about an event, project, or issue, this theory is applied by researcher to verify the assumption of the agenda-setting theory. In this context, assessing the print media agenda about CPEC news stories coverage in The News International and China Daily. Kiousis, Popescu and Mitrook (2007) describe that Agenda setting is a theory of mass communication states that how mass media interacts and affects the audience it targets. The streamline of theory is that mass media develops a rudimentary interface between the public and world around them. While an individual can learn about free existing physical world around him through sensation and personal observation, they rely on mass media to aware them of the world beyond their limit of access. For example, there might be very fewer people who might have travel the whole world but due to mass media, every person on earth can have access and information about any place on earth. Thus, the media holds control over the public's perception of the world around them. The control is not just to the extinct of what to think about, but also how to think about it. The arguments made by agenda-setting are vivid and have wide impact on societal communication level.

\section{RESEARCH METHODOLOGY}

The researchers applied a quantitative content analysis methodology to measure phenomena. This study has been conducted through content analysis to study the stories related to CPEC in two famous newspapers from Pakistan named The News International and China Daily of China. Print media of both countries' newspapers; The News International Pakistan and China Daily were the universe of study. Daily the News International is the largest newspaper in Pakistan. It is $\mathrm{ABC}$ certified and its circulation is 140,000. It is the second-highest circulated newspaper in Pakistan (Rack, May, 17, 2020). China daily is a high circulated newspaper in the country. In more than 150 countries it has been circulated, whereas, 900,000 copies circulation around the globe. The motto of daily is "Let the world know about China, let China go to the world" (China Daily, May 17, 2020). The purposive sampling technique was used by researchers for collection of data from the timeframe of 1st January 2018 to 30th June 2018. The researchers screened those news stories related to CPEC in the selected newspapers. A coding sheet was used for the collection of data. Inter-coder reliability is method to find out consistency between codes rated by two different data collection (Charumathi, \& Ramesh, 2013). The methods for the inter-coder reliability check are; the percent agreement, Bennett, Scott's pi, Fleiss's, Cohen's kappa (2014), Krippendorff's alpha and Cronbach's alpha, Chi-square, and Pearson's R (Nili, Tate, \& Barros, 2017). In this connection, in this research, the researchers applied Cohen's kappa method for reliability.

Table 1

Symmetric Measures

\begin{tabular}{lcccc}
\hline & Value & ASE & Approx. Tb & Approx. Sig. \\
\hline Measure of Kappa Agreement & .812 & .089 & 7.421 & .000 \\
N of Valid Cases & 90 & & & \\
\hline
\end{tabular}

Cohen's $\kappa$ was applied to verify the agreement between two coder's judgment about the China Pakistan Economic Corridor to examine the strengths and weaknesses related with the project. The results of the test indicate an acceptable agreement of $8 \%$ between two coders $\kappa=.812$, $\mathrm{p}<$.000. 


\section{RESULTS AND DISCUSSION}

The researcher used descriptive and inferential statistics for data analysis. The researcher also compared the data to dig out the coverage of CPEC in The News International and China Daily. The News International published $63.4 \%$ of the stories analyzed while China Daily published $35.7 \%$ of them from January 1 to June 30th, 2018.A total of 90 stories had been published in both newspapers. In both newspapers, $44.4 \%$ of the stories were published on the business page, $20 \%$ were published on the World page, and $17.8 \%$ were published on the front and back pages. However,31.3\% of the stories were comprised of 4 columns, $28.9 \%$ of 3 columns, $8.9 \%$ of 6 columns, $5.6 \%, 6.7 \%, 2.2 \%$, and $1.1 \%$ stories of $1,6,7$, and 8 columns, respectively. Percentage of the sources is $41.1,28.9,11.1,11.1$, and 7.8 for the staff reporter, news desk, AFP, INP, APP, respectively.

\section{Table 2}

Distribution of News based on Strengths and Weaknesses of CPEC

\begin{tabular}{lcclcc}
\hline \multicolumn{2}{c}{ Strengths } & \multicolumn{3}{c}{ Weaknesses } \\
\hline Variables & Frequency & $\%$ & Variables & Frequency & $\%$ \\
Revenue \& Economy & 62 & 68.9 & Depth \& Economic Aid & 31 & 34.4 \\
Service \& Employment & 35 & 38.9 & Environmental Destruction & 00 & 00.0 \\
Transport \& Infrastructure & 47 & 52.2 & Cheap Labor & 02 & 02.2 \\
Energy and Power & 39 & 43.3 & Ethnic Conflicts \& IR & 29 & 32.2 \\
Investment \& Security & 64 & 71.10 & Sovereignty & 17 & 18.9 \\
\hline
\end{tabular}

After the comparison, the above table demonstrates the coverage of both the newspapers' news stories published regarding CPEC based on the nature of frames i.e., strengths and weaknesses. It highlights that 62 times the news stories appeared in the frame of Revenue and Economy in both the newspapers. On the other hand, debt and economic aid were framed in 31 news stories in both the newspapers. Services and employment were framed 35 times in comparison to the environmental destruction that is not framed in either newspaper. Transport \& infrastructure was highlighted 47 times and the cheap labor was framed only 02 times in both the newspapers' stories. Energy and Power were framed 39 times in the news stories while ethnic conflicts and international relations were framed 29 times in The News International and the China Daily. Investment \& Security was highlighted the most. It was framed in both the newspapers 64 times, making up to $71.10 \%$, in comparison to the sovereignty, which was framed 17 times in both the newspapers.

\section{H1:}

The News International and China Daily give Positive Coverage to Revenue \& Economy than Debt \& Economic Aid regarding CPEC

\begin{tabular}{lccc}
\hline & The News International & China Daily & Total \\
\hline Revenue \& Economy & 39 & 23 & 62 \\
Debt and Economic Aid & 22 & 09 & 31 \\
\hline
\end{tabular}

More positive coverage of revenue and economy than debt and economic aid about CPEC was observed in The News International and China Daily. While 62 stories were published with the frame of revenue and economy, 31 were published with the frame of debt and economic aid. The results of the study supported the hypothesis that both the country`s newspapers give positive 
and more coverage to both the nation `s economy and their revenue generation, in contrast with realization of economic aid and debt, especially for Pakistan. Although officially supporting the BRI by International Monitory Fund (IMF), they published a warning in April 2018 that China is doing investment in BRI projects and billions of dollars have been showered on the projects which are unsustainable and unneeded projects which will eventually lead to the unpayable and heavy burden of debts (Glover, 2018). Additionally, a report published that o8 countries under the flagship of BRI are already straggling with severe debt situation and 23 countries are facing financial management risk due to high level of dues since $201323 \%$ of project is reported to has delaying bills, market mismanagement and public opposition has erupted in national security debate.

\section{H2:}

The News International framed positively the Infrastructure and Transport regarding CPEC as compared to China Daily about CPEC

\begin{tabular}{lcc}
\hline & Infrastructure and transport & Total \\
\hline The News International & 27 & 57 \\
China Daily & 20 & 33 \\
\hline
\end{tabular}

The News International gave more positive coverage to infrastructure and transport than China Daily, as it published 27 stories and the China Daily published 20 stories. Javaid, (2016) argued that through CPEC initiative between Pakistan and China is a multi-million dollar project that will link China to two-third of the world via Pakistan `s Gwadar port, the project will integrate $2000 \mathrm{~km}$ transport link through railway lines, roads, and oil and gas pipelines from Kashgar to Gwadar, with CPEC and Gawader port being functional, delivery time and shipping cost would reduce magnificently and thus allowing China to do a smooth trade with middle east and rest of world, so eventually there will be an increase in Pakistan `s economy. Moreover, the country will overcome shortage of energy crises and expanding communication infrastructure and transport facilities.

\section{H3:}

The News International and China Daily framed coverage of energy and power in a positive way rather than Ethnic conflict and International Relations about CPEC

\begin{tabular}{lccc}
\hline Variables & The News International & China Daily & Total \\
\hline Energy \& power & 19 & 20 & 39 \\
Ethnic Conflict \& International Relations & 21 & 08 & 29 \\
\hline
\end{tabular}

Both The News International and China Daily gave more coverage to energy and power than the ethnic conflicts and international relations, leading to a more positive framing of CPEC. A total of 39 stories were published with the former frame as compared with 29 with the latter frame. Total investment for CPEC projects is estimated at $\$ 46$ billion, where according to The Board of Investment (BOI), 74\% of total CPEC investment is dedicated to energy projects, due to the extreme significance to energy and power projects in CPEC it is known as Pakistan China Energy and Economic Corridor (PCEEC), there are various energy projects like coal energy, solar, hydro energy and wind energy projects (Shah, 2015). A 17,00o Mega Watt power generation will be added to the national grid through various projects including hydropower, wind, solar, coal 
energy projects which will solve the shortfall and load shedding in Pakistan, which will certainly play a vital role in boosting country's economy. With this large investment by China in Pakistan through CPEC, there are certain implications and threats that are inevitable to development of project.

H4:

The News International gives more coverage to Services and Employment as compared to China Daily regarding CPEC

\begin{tabular}{lcc}
\hline & Services \& Employment & Total \\
\hline The News International & 18 & 57 \\
China Daily & 17 & 33 \\
\hline
\end{tabular}

The News International gave more coverage to service and employment than China Daily, as it published 18 stories and China Daily published 17 stories have frame services and employment. According to Human Development Index by UNDP (2015), Pakistan is positioned in low human development countries, in which country is ranked 147 out the 188 countries. Hameed (2016), suggested that a developing country like Pakistan faces a rise in unemployment across country, employment is considered to be one of main indicators for development, it can enhance social welfare and bring country from extreme poverty to dynamic state and certainly bring prosperity to country. In current situation with the CPEC initiative, it is predicted that more 700,000 direct jobs between 2015 to 2030, adding between 2 to $2.5 \%$ growth in the GDP in a fiscal year of the country.

H5:

The News International and China Daily give positive coverage to Investment and security as compared to sovereignty about CPEC

\begin{tabular}{lccc}
\hline Variables & The News International & China Daily & Total \\
\hline Investment \& Security & 44 & 20 & 64 \\
Sovereignty & 08 & 09 & 17 \\
\hline
\end{tabular}

Both The News International and China Daily give more coverage to the investment and security than sovereignty. A total of 64 stories were published with the frame of investment and security in papers while only 17 with frame sovereignty were published. Hurley, Morris and Portelance (2019), suggested that a significant question arises on the integrity of Chinese investment in the BRI countries and the unsustainable projects in their respective countries, many associated countries are under the heavy debt of China, and these countries are experiencing sovereignty concerns and delay in the projects due to unpaid cycled leasing on the projects, in which these nations are experiencing a negative impact on their economy. the most relatable example is Sri Lanka where China has invested around the US \$ 55 Billion, which is roughly $10 \%$ of the total debt of the country (Markar, 2018). A Chinese owned private company built a deep seaport in the city of the Hambantota under BRI, and after falling into the Chinese 'debt trap design' to accommodate that the US $\$ 1.1$ billion was written off, in exchange 99-year lease were signed between Sri Lanka and Chinese company, which ultimately affected their sovereignty. Mccombs and Shaw (1972) argued the concept of the agenda-setting theory that when media focuses on 
one specific issue, public tends to perceive those issues as more important than other issues in certainty.

Both the newspapers gave a fair amount of coverage to CPEC especially The News International a highly circulated English paper in the Pakistan; that dwells on the fact that China Pakistan Economic Corridor will certainly change the fate of the country and this amount of coverage will create awareness amongst the policymakers, businessmen, researchers and the common people of the country, whereas the Chinese publication focuses more on BRI (Belt Road Initiative) than CPEC. The Chinese newspapers have the worldwide readership, so they should concentrate on CPEC in the news stories as they frame BRI, which will create awareness on a global level about the significance of CPEC. Nazir, Ali and Farooq (2018) carried out a Comparative study under the title 'Emergence of CPEC in the Pakistani Leading newspapers' they observed the overall positive and negative factors in two leading Urdu newspapers of Pakistan regarding CPEC using a quantitative method applying content analysis to determine the nature of the entire 2016 news stories in both the newspapers, their finding concluded that 88.9\% news stories were framed positively and only $11.1 \%$ stories were framed negatively, they debated that media is playing its effective role in portraying the positive image of project, positive statement of the government and authorities are more highlighted in both the newspapers, therefore resulting in eradication the formal gap between the authorities and the stakeholders and creating the bridge between them.

The findings of this study suggest that both the Countries ` Newspapers highlighted mostly the positive aspects of the project instead of negative to the residence of both countries and framed their news stories in way that encourage stakeholders in acquiring maximum reimbursements from the project (Nazir et al., 2018). In total, this study would contribute to the international relations, foreign policy, policy studies, and security studies generally and journalism-related studies particularly. The findings of this research are similar to the results of Alam et al. (2019), Ali (2018); Hussian (2017), Rehman, Khan and Jaffry, 2017); Yousuf (2018), Makhdoomi (2016) Harris (2018); and Farooq (2020). This study strengthened the assumptions of the Agendasetting theory that media is set the agenda to promote some issues. The same methodology was applied by Abid and Ashfaq (2015); Dong (2016), Hameed (2016); Irshad (2015); and Yousuf (2018).

\section{CONCLUSION}

The study aimed to explore the coverage of CPEC framed in the news stories and to find out the differences in project's portrayal by both the countries' leading newspapers. Data was collected from the front page, back page, business page, and world page. Coding sheets were designed to collect data about selected variables from January 1, 2018, to June 30, 2018. The variables were divided into two frames: strengths and weaknesses. The strength frame includes revenue and economy, services and employment, transport and the infrastructure, energy and power and the weaknesses frame consists of investment and security, debt and economic aid, environmental destruction, cheap labor, ethnic conflict and international relations, and sovereignty. The News International gave more coverage to CPEC than China Daily (Daily China, 2019) in a total of 90 stories covered in both the newspapers. Individually, both newspapers, The News International (The News International, 2019) published 57 stories and China Daily published 33 news stories about the issues related with the CPEC. Investment and economy, a frame of strength, was the 
most covered frame in both the newspapers, appearing 64 and 62 effective times in these papers respectively.

While, The News International showed more concern about ethnic conflicts and international relations, which is considered as weak frame by the researcher in the study, both the newspapers gave almost equal coverage to the frames' infrastructure, energy, and employment, which are considered Strength Frames in the study by the researcher. Debt and financial aid, a weakness frame, appeared 22 times in 57 of The News International's stories, whereas China Daily focused more on economy and investment; the frame appearing in 23 and 20 stories in these newspapers respectively. The first aim of the study was to analyze the coverage of CPEC and how it is framed in news stories of both China's and Pakistan's leading newspapers named News International and China Daily. It was concluded that both the newspapers gave a fair amount of coverage to CPEC and framed almost every variable of the study. The second aim of the study was to find out the differences in the project's portrayal by both countries' leading newspapers, and it was concluded by the researcher in study that both the newspapers highlighted the strength frames more than weakness frames and highlighted positive aspects of CPEC rather than its negative aspect.

\section{REFERENCES}

Abid, M., \& Ashfaq, A. (2015). CPEC: Challenges and opportunities for Pakistan. Journal of Pakistan Vision, 16 (2), 142-169.

Alam, K. M., Li, X., \& Baig, S. (2019). Impact of transport cost and travel time on trade under China-Pakistan Economic Corridor (CPEC). Journal of Advanced Transportation, 2019.

Ali, M. (2018). The China-Pakistan Economic Corridor: Tapping Potential to Achieve the 2030 Agenda in Pakistan. China Quarterly of International Strategic Studies, 4 (02), 301-325.

Charumathi, B., \& Ramesh, L. (2013). Voluntary disclosures by Nifty Companies: A content analysis. Indian Accounting Review, 17(2), 67-82.

China Daily (May 17, 2020), China Daily's Print Media, retrieved from http://www.chinadaily.com.cn /static e/printmedia.html.

Connor, R. (2015). The United Nations world water development report 2015: water for a sustainable world (Vol. 1). UNESCO publishing

Daily China (April 2, 2019) "The History of the Daily China" Retrieved from http://www.chinadaily.com.cn

Dong, M. U. A. Z. H. China Pakistan Economic Corridor: A Spatial Analysis on the Security Risk of CPEC. International Journal for Innovative Research in Multidisciplinary Field, 2(9), 100-103.

Elizabeth, A. F., \& Aransi, W. O. (2020). Influence of Mass Media on Sustainable Development Goal One Attainment in Osun State, Nigeria. Humanities, 5 (1), 1-16.

Farooq, A. (2020). Revisiting CPEC: A Corridor of Opportunities. Journal of Social and Political Sciences, 3(1).

Glover. C, (2018), “IMF's Lagarde Warns China on Belt and Road Debt”, Financial Times, retrieved fromhttps://www.ft.com/content/8e6d98e2-3ded-11e8-b7eo-52972418fec4

Hameed, H. (2016). Pakistans print media presentation of Pakistan China relation and new silk route corridor project (A Case Study of Chinese President Xi JinPing Visit Days). Journal of Political Sciences \& Public Affairs. 
Harris, J. R. (2018). Who leads global capitalism? The unlikely rise of China. Class, Race and Corporate Power, 6(1), 8.

Hurley, J., Morris, S., \& Portelance, G. (2019). Examining the debt implications of the Belt and Road Initiative from a policy perspective. Journal of Infrastructure, Policy and Development, 3 (1), 139-175.

Hussain, Z. (2017). The China-Pakistan economic corridor and the new regional geopolitics. Asian visions, 94.

Irshad, M. S. (2015). One belt and one road: dose China-Pakistan economic corridor benefit for Pakistan's economy? Journal of Economics and Sustainable Development, 6(24).

Kiousis, S., Popescu, C., \& Mitrook, M. (2007). Understanding influence on corporate reputation: An examination of public relations efforts, media coverage, public opinion, and financial performance from an agenda-building and agenda-setting perspective. Journal of Public Relations Research, 19 (2), 147-165.

Makhdoomi. M (2016), CPEC and Pakistan, retrieved from http://www.greaterkashmir.com/news/ opinion/story/205841.html.

Malik, A. R. (2018). The China-Pakistan Economic Corridor (CPEC): a game changer for Pakistan's economy. In China's Global Rebalancing and the New Silk Road (pp. 69-83). Springer, Singapore.

Markar, M. M. (2018). "Sri Lanka Sinks Deeper into China's Grasp as Debt Woes Spiral”, Retrieved from https://asia.nikkei.com/Spotlight/Belt-and-Road/Sri-Lanka-sinksdeeper-into-China-s-grasp-as-debt-woes-spiral.

McCombs, M. E., \& Shaw, D. L. (1972). The agenda-setting function of mass media. Public opinion quarterly, 36 (2), 176-187.

Mengal, T. M., Hussain, S., Taj, M. K., Liang, Z., \& Taj, I. (2018). Role of Print Media in ChinaPakistan Economic Corridor as Stakeholder. International Journal of Business, Economics and Management Works, 5 (12), 32-35.

Mirza, F. M., Fatima, N., \& Ullah, K. (2019). Impact of China-Pakistan economic corridor on Pakistan's future energy consumption and energy saving potential: Evidence from sectoral time series analysis. Energy Strategy Reviews, 25, 34-46.

Nazir, F., Ali, A., \& Farooq, M. (2018). Emergence of CPEC in the Pakistani Leading Urdu Newspapers. Global Regional Review, 4 (3), 348-359.

Nili, A., Tate, M., \& Barros, A. (2017). A critical analysis of inter-coder reliability methods in information systems research.

Rack (May, 17, 2020) The News International Newspaper, retrieved fromhttps://muckrack.com/media-outlet/thenews.

Rehman, M. Z., Khan, A., \& Jaffry, Q. R. (2017). Emerging Political Economy of CPEC Future Dynamics and Perspectives for Pakistan. Global Social Sciences Review, 2 (2), 24-40.

Shah. S, (20 April 2015) "China "s Xi Jinping Launches Investment Deal in Pakistan", Retrieved from https://www.wsj.com/articles/chinas-xi-jinping-set-to-launch-investment-dealin-pakistan-1429 533767.

The News International (April 2, 2019) "History of The News International" Retrieved from http://www.apns.com.pk/news agencies/index.php.

Yousafa, Z., Ahmedb, M., \& Fiazc, M. (2018). Framing of China Pak Economic Corridor (CPEC) in the Leading Press of Pakistan and China. The Pakistan Journal of Social Sciences, special Issue, June, 2018, 163-173. 